\title{
IMPLEMENTASI MANAJEMEN ORGANISASI “HISADA” SEBAGAI WADAH KEPEMIMPINAN SANTRI
}

\section{IMPLEMENTATION OF “HISADA” ORGANIZATIONAL MANAGEMENT AS A OF STUDENT'S LEADERSHIP FACILITATOR}

\author{
A Kholik ${ }^{1 a}$ dan RS Suharyati ${ }^{1}$ \\ 1 Program Studi Manajemen Pendidikan Islam, Fakultas Keguruan dan Ilmu Pendidikan, \\ Universitas Djuanda Bogor, Jl. Tol Ciawi No. 1 Kotak Pos 35 Ciawi Bogor 16720 \\ a Korespondensi: Abdul Kholik, Email: abdul.kholik@unida.ac.id \\ (Diterima: 20-08-2017; Ditelaah: 20-08-2017; Disetujui: 24-09-2017)
}

\begin{abstract}
Association of Santri Darul Ulum or usually called as HISADA, has a strategic role in the continuity of education process at Daarul Uluum School. As an internal school organization, HISADA is required to be a facilitator in growing the soul of santri leadership which is known as one of the school goals. Therefore, implementation of HISADA organizational management becomes very important in achieving one of the school goals to be more effective and efficient. The purpose of this study was to describe HISADA management functions related to planning, organizing, implementing and monitoring. Data were collected through observation, interviews, and documentation. The study used a qualitative approach with case study method. The validity of the data used a credibility test conducted by prolonging the time of research, was increasing research and triangulation of data persistence. The results of this study is to describe: 1) operational planning conducted for a period of one year through HISADA work deliberation, 2) organizing carried out through several stages to enhance HISADA organizational structure, 3) implementation of HISADA's program goes well even though there are some obstacles to be minimized, 4) supervision form conducted by the board of HISADA is both direct and indirect supervision.
\end{abstract}

Keywords: leadership, management, organization, santri.

\begin{abstract}
ABSTRAK
Organisasi HISADA (Himpunan Santri Daarul Uluum), memililki peran strategis dalam keberlangsungan proses pendidikan di sekolah Daarul Uluum. Sebagai sebuah organisasi di lingkungan sekolah, HISADA dituntut untuk bisa menjadi wadah dalam menumbuhkan jiwa kepemimpinan santri yang merupakan salah satu tujuan sekolah. Oleh sebab itu, pelaksanaan manajemen organisasi HISADA menjadi sangat penting dalam pencapaian salah satu tujuan sekolah yang lebih efektif dan efisien. Penelitian ini bertujuan untuk mendeskripsikan fungsi manajemen organisasi HISADA terkait perencanaan, pengorganisasian, pelaksanaan, dan pengawasan. Data yang dikumpulkan melalui observasi, wawancara, dan studi dokumentasi. Penelitian ini menggunakan pendekatan kualitatif dengan metode studi kasus. Validitas data yang digunakan dalam penelitian ini adalah dengan menggunakn uji kredibilitas yang dilakukan dengan memperpanjang waktu penelitian, meningkatkan ketekunan peneliti dan triangulasi data. Hasil penelitian ini menggambarkan bagaimana fungsi-fungsi manajemen organisasi HISADA yang terdiri dari: 1) perencanaan operasional yang dilakukan untuk jangka waktu satu tahun melalui musyawarah kerja HISADA sebagai langkah awal dari bentuk wadah kepemimpinan santri; 2) pengorganisasian dilakukan melalui beberapa tahapan hingga menghasilkan struktur
\end{abstract}


organisasi HISADA dengan susunan personalia dan pembagian tugas yang terbagi ke dalam delapan bagian pada organisasi HISADA; 3) pelaksanaan dalam organisasi HISADA berjalan dengan baik melalui beberapa kegiatan yang sudah dirumuskan dalam program kerja pada setiap bagian organisasi HISADA yang dapat mengasah jiwa kepemimpinan santri meskipun masih ada hambatan yang dialami; 4) bentuk pengawasan yang dilakukan oleh pengurus HISADA dalam organisasi HISADA adalah bentuk pengawasan langsung dan tidak langsung. Pengawasan secara langsung dilakukan ketua dan wakil HISADA kepada pengurus organisasi dan santri lainnya. Sementara itu, pengawasan tidak langsung dilakukan dengan menunjuk jasus (mata-mata).

Kata kunci: kepemimpinan, manajemen, organisasi, santri.

Kholik A dan RS Suharyati. 2017. Implementasi manajemen organisasi HISADA sebagai wadah kepemimpinan santri. Tadbir Muwahhid 1(2): 129-142.

\section{PENDAHULUAN}

Pesantren Modern Daarul Uluum Lido adalah sebuah lembaga pendidikan Islam berbasis asrama dengan sistem yang modern. Jumlah santri di Pesantren Modern Daarul Uluum Lido adalah 2.260 santri (dokumen sekretariat pesantren tahun ajaran 2016-2017). Sehingga dengan jumlah tersebut, kyai selaku pimpinan pesantren membutuhkan tenaga khusus untuk melakukan pengawasan terhadap santri. Pimpinan pesantren kemudian membentuk sebuah organisasi santri yang dinamakan HISADA (Himpunan Santri Daarul Uluum). HISADA adalah organisasi resmi yang ditetapkan pesantren sebagai wadah organisasi tertinggi dan sah keberadaannya di TMI (Tarbiyatul Mu'allimin Al-Islamiyyah) Pesantren Modern Daarul Uluum Lido.

Organisasi HISADA merupakan sebuah media latihan dalam berorganisasi, baik sebagai anggota maupun pengurus. Media latihan para santri untuk menjadi seorang pemimpin di masa depan yang amanah dan bertanggung jawab. HISADA merupakan ujung tombak pesantren, membantu pimpinan pesantren untuk memobilisasi semua kegiatan santri di pesantren.

Secara umum program kerja HISADA adalah membantu pimpinan pesantren dalam menggerakan santri untuk disiplin dalam hal sholat berjama'ah di masjid, menggunakan bahasa sehari-hari yang dipakai para santri yaitu Bahasa Arab dan Bahasa Inggris, mengurus santri yang sakit, menggerakan santri untuk berolahraga pada hari ahad, mengadakan pengabsenan santri setiap malam, menyiapkan peralatan dalam setiap acara HISADA, dan menggerakkan santri untuk mengikuti kegiatan pramuka. Selain membuat program kerja, pengurus HISADA membuat peraturan untuk melatih kedisiplinan para anggota.

Beberapa pengurus HISADA masih ada yang sulit untuk melaksanakan program kerja dan peraturan yang telah disepakati bersama. Hal tersebut dilihat dari masih ditemukan pengurus HISADA yang melanggar program kerja dan peraturan yang telah disepakati bersama, seperti merokok, keluar pesantren tanpa izin dan membawa alat elektronik. Seharusnya, pengurus HISADA menjadi figur dan contoh yang baik bagi para santri yang diurusnya. Apalagi pengurus HISADA berperan dalam pembuatan program kerja dan peraturan. Hal ini menjadi permasalahan dalam mengurus para santri. Masalah lain yang menjadi penghambat adalah kurangnya koordinasi yang baik antara sesama bagian dalam HISADA, sarana dan prasarana yang 
kurang mendukung terlaksananya program kerja para pengurus HISADA. Kurangnya dukungan dari beberapa wali santri atas program kerja HISADA dan peraturan yang telah ditetapkan menjadi salah satu faktor penghambat terlaksananya program kerja pengurus HISADA.

Untuk menjalankan sebuah organisasi yang baik, manajemen organisasi sangat dibutuhkan. Manajemen sebagai suatu proses khas yang terdiri atas tindakantindakan perencanaan, pengorganisasian, penggerakan, pengendalian yang dilakukan untuk menentukan serta mencapai sasaran yang telah ditentukan melalui pemanfaatan sumber daya manusia dan sumber daya lainnya (Silalahi 2011).

Organisasi merupakan suatu kelompok manusia yang berinteraksi melakukan berbagai kegiatan secara koordinasi untuk mencapai tujuan, dimana pada dasarnya bahwa individu tidak dapat mencapai tujuan secara sendiri-sendiri. Secara umum organisasi dapat diartikan sebagai pembentukan sebuah struktur. Menempatkan beberapa orang atau kelompok dalam suatu struktur organisasi dengan tugas dan fungsi berdasarkan bidang dan kemampuannya (Priyono 2007). Pemikiran perlunya manajemen organisasi yang baik dalam organisasi HISADA dipandang sebagai sebuah kebutuhan pengurus HISADA untuk mengurus jumlah santri yang banyak dan menghadapi berbagai permasalahan dalam kepengurusan HISADA. Sebuah manajemen dalam organisasi HISADA memiliki peran penting agar kegiatan santri dapat berjalan secara efektif.

\section{MATERI DAN METODE}

\section{Materi}

\section{Hakikat Manajemen Organisasi}

Menurut George R. Terry yang dikutip oleh Silalahi (2011) menyatakan bahwa manajemen adalah sebagai suatu proses khas yang terdiri atas tindakan-tindakan perencanaan, pengorganisasian, penggerakan, pengendalian yang dilakukan untuk menentukan serta mencapai sasaran yang telah ditentukan melalui pemanfaatan sumber daya manusia dan sumber daya lainnya. Dari pendapat tersebut dapat ditarik kesimpulan bahwa manajemen adalah suatu cabang ilmu pengetahuan yang membahas tentang teknik atau cara mengatur suatu perusahaan atau lembaga yang memanfaatkan sumber daya manusia dengan mengoptimalkan fungsi manajemen berupa perencanaan, pengorganisasian, penggerakan, pengarahan dan pengawasan demi tercapainya tujuan bersama.

Hakikat manajemen di dalam Al-Qur'an memiliki kata at-tadbir yang bermakna (pengaturan) (Ramayulis 2008). Kata tersebut merupakan derivasi dari kata dabbara (mengatur) yang banyak terdapat dalam Al-Qur'an Surat As-Sajdah ayat 5:

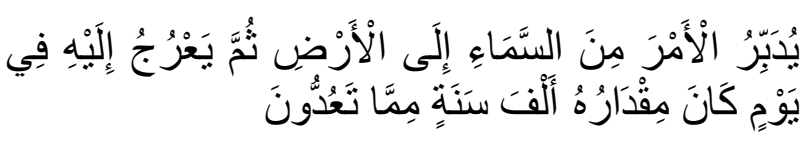

Artinya: "Dia mengatur urusan dari langit ke bumi, kemudian (urusan) itu naik kepadaNya dalam satu hari yang kadarnya adalah seribu tahun menurut perhitunganmu" (Kementrian Agama, Al- Qur'an dan Terjemahan An-Nafi' 2016). 
Berdasarkan ayat tersebut dapat terlihat bahwa Allah SWT merupakan pengatur alam semesta. Allah sebagai manager dalam penciptaan alam semesta beserta isinya. Namun Allah memerintahkan manusia sebagai khalifah di muka bumi untuk mengatur dan menjaga alam yang sudah Allah ciptakan.

Salah satu yang dikelola dalam manajemen adalah sebuah organisasi. Baik organisasi yang lingkupnya besar maupun kecil. Di dalam suatu organisasi manajemen merupakan unsur penting sebagai acuan untuk mencapai tujuan organisasi. Menurut Jhon R. Schermerhom, Jr. (Silalahi 2011) bahwa organisasi diartikan sebagai an organization is collection of people working together to achieve a common person (sekumpulan orang yang bekerjasama untuk mencapai tujuan bersama). Jadi, organisasi adalah kumpulan dari beberapa orang yang melakukan suatu pekerjaan, dikerjakan secara bersama-sama dan memiliki tujuan bersama. Tidak jauh berbeda dengan Silalahi, Usman (2014) memberikan definisi bahwa organisasi adalah proses kerjasama dua orang atau lebih untuk mencapai tujuan bersama secara efektif dan efisien.

Manajemen organisasi adalah proses mengelola organisasi agar dapat mencapai tujuan. Pengelolaan yang dilakukan dengan membuat orang bekerjasama pada satu wadah yang sama. Proses manajemen untuk organisasi bukanlah sebuah proses yang mudah. Proses mencapai tujuan tidak bisa asal-asalan, selain harus memastikan tujuan utama tercapai, proses tersebut juga harus mempertimbangkan dua aspek penting, yaitu keefektifitasan dan keefisienan dari proses pencapaian tersebut. Manajemen organisasi merupakan proses lanjutan setelah proses penentuan strategi untuk mencapai visi dan misi organisasi.
Manajemen organisasi menjadi hal penting dalam menerapkan strategi yang telah ditentukan. Manajemen organisasi yang baik apabila dapat mengoptimalkan sumber daya yang dimiliki organisasi melalui perencanaan, pengorganisasian, pelaksanaan dan pengawasan.

Fungsi-fungsi manajemen organisasi merupakan elemen penting dalam suatu manajemen organisasi. Fungsi manajemen menjadi acuan pada sebuah organisasi dalam melaksanakan tugas organisasi tersebut. Fungsi manajemen organisasi pada dasarnya sama dengan fungsi manajemen pada umumnya. Menurut Terry (Marno dkk, 2008) fungsi manajemen terdiri atas: planning, organizing, actuating, dan controlling, fungsi manajemen tersebut berupa perencanaan, pengorganisasian, pengarahan, dan pengawasan. Sedangkan Henry Fayol (Badruddin, 2014) menyatakan bahwa fungsi manajemen adalah planning, organizing, commanding, coordinating, and controlling.

Berdasarkan kedua pendapat ahli tersebut dapat disimpulkan bahwa fungsi manajemen organisasi adalah sebagai berikut:

\section{Perencanaan}

Menurut James F. Stoner dan R. Edward Freeman yang dikutip oleh Silalahi (2011), bahwa perencanaan adalah: planning is the process of establishing goals and suitable courses of action for achieving those goals. Artinya sebuah perencanaan merupakan kegiatan yang dilakukan oleh sebuah kelompok dalam mempersiapkan hal yang akan dilakukan pada kurun waktu tertentu untuk mencapai suatu tujuan.

\section{Pengorganisasian.}

Pengorganisasian yaitu proses penyusunan struktur organisasi yang sesuai dengan tujuan organisasi, sumber daya- 
sumber daya yang dimilikinya, dan lingkungan yang melingkupinya (Handoko, 2015).

\section{Pelaksanaan}

Menurut Badruddin (2014) pelaksanaan adalah suatu tindakan dari sebuah rencana yang sudah disusun secara matang dan terperinci. Pelaksanaan dalam manajemen lebih dikenal dengan bahasa implementasi program. Senada dengan apa yang disamapikan Badruddin, Zenju (2008) memberikan definisi bahwa pelaksanaan atau actuating adalah pemberian dorongan semangat dan penjurusan aktivitas bawahan agar menuju tujuan yang dikehendaki dan rencana yang telah ditetapkan.

\section{Pengendalian}

Gareth R. Jones dan Jennifer M. George yang dikutip Silalahi (2011) mengatakan: "Controlling is the process whereby managers monitor and regulate how efficiently and effectively an organization and its members are performing the activities necessary to ac hieveorganizational goals."

Maksud dari pernyataan tersebut bahwa pengendalian merupakan proses memonitor dan mengatur sejauh mana kefektifan dan keefisienan sebuah pekerjaan yang berada dalam suatu organisasi dan kemampuan anggota dalam melaksanakan tugas untuk mencapai tujuan organisasi.

\section{Hakikat Kepemimpinan Santri}

Kepemimpinan dalam Bahasa Indonesia merupakan asal kata dari pemimpin yang diberi imbuhan ke-an. G.R. Terry (Silalahi, 2011) mengungkapkan bahwa kepemimpinan adalah "Kemampuan mengarahkan pengikut-pengikutnya untuk bekerja sama dengan kepercayaan serta tekun mengerjakan tugas-tugas yang diberikan oleh pemimpin mereka." Menurut pengertian tersebut kepemimpinan adalah kemampuan yang dimiliki oleh pemimpin dalam memberikan arahan berupa tugas dan pembagian kerja kepada para anggota agar mau bekerjasama untuk mencapai tujuan.

Kata santri menurut Kamus Besar Bahasa Indonesia adalah orang yang mendalami pengajiannya dalam agama Islam dengan berguru ke tempat yang jauh seperti pesantren (Depdiknas, 2015). Berdasarkan pengertian tersebut santri merupakan orang yang pergi merantau dalam rangka memperdalam ajaran agama Islam ke suatu tempat yang dinamakan pesantren.

Kata santri berasal dari kata cantrik (bahasa Sansekerta, atau mungkin Jawa) yang berarti orang yang selalu mengikuti guru, yang kemudian dikembangkan oleh Perguruan Taman Siswa dalam sistem asrama yang disebut Pawiyatan (Rohadi $\mathrm{dkk}, 2008)$. Istilah santri hanya terdapat di pesantren sebagai pengenjawatahan adanya peserta didik yang haus akan ilmu pengetahuan yang dimiliki oleh seorang kyai yang memimpin sebuah pesantren (Bahri, 2001). Berdasarkan pengertian tersebut santri merupakan peserta didik yang menuntut ilmu pengetahuan yang diberikan oleh seorang kyai yang menjadi pemimpin dari sebuah pesantren.

Dari berbagai definisi mengenai kepemimpinan dan santri di atas, penulis dalam hal ini menyimpulkan bahwa kepemimpinan santri adalah kemampuan seorang santri untuk mengajak para anggota dalam suatu organisasi santri untuk melaksanakan tugas dan fungsi dari organisasi tersebut. Kepemimpinan santri adalah proses mempengaruhi dan memberi contoh yang baik kepada pengurus organisasi dan anggota, baik sikap maupun perkataan 


\section{Hakikat Organisasi HISADA sebagai Organisasi Santri}

Organisasi santri dengan berbagai kegiatan ekstrakulikulernya akan berfungsi sebagai wahana berlatih di bidang keorganisasian, kepemimpinan, dan keterampilan. Dengan terbiasa berorganisasi, berlatih, dan memecahkan masalah ketika waktu muda, maka para santri memiliki kemampuan dalam menghadapi berbagai persoalan yang lebih besar, ketika telah berada di tengah masyarakat.

Tujuan dibentuknya organisasi santri adalah untuk melancarkan kegiatan pondok pesantren, memudahkan kontrol terhadap aktivitas santri, meringankan tanggung jawab pengasuh dan pengurus. Dalam pembentukan organisasi santri perlu adanya prinsip koordinatif, konsulatif, partisipatif, kekompakan, dan tanggung jawab (MU YAPPI, 2008).

Setiap pondok pesantren yang jenisnya modern membentuk organisasi santri dengan nama yang berbeda. Pesantren Modern Daarul Uluum Lido memiliki nama oganisasi santri yaitu HISADA (Himpunan Santri Daarul Uluum). Organisasi HISADA yang dibentuk oleh Pesantren Modern Daarul Uluum Lido menjadi wadah kepemimpinan para santri melalui berbagai macam kegiatan.

Tidak hanya di Pesantren Modern Daarul Uluum Lido, pada Pondok Modern Gontor juga memiliki organisasi santri yang dinamakan OPPM (Organisasi Pelajar Pondok Modern). Pelaksana OPPM adalah santri kelas akhir yang terpilih secara demokratis dan terpimpin. Kegiatankegiatan santri di dalam pondok diurus oleh 20 bagian di bawah OPPM. Organisasi Pelajar Pondok Modern ini membawahi beberapa organisasi, antara lain: organisasi asrama, klub-klub keterampilan dan klub bahasa.

Selain itu, OSDN adalah organisasi santri yang dibentuk oleh Pondok Pesantren Daarunnajah. Penentuan siapa yang berhak maju untuk mencalonkan diri sebagai ketua adalah berdasarkan proses evaluasi santri dengan rekor terbaik selama 5 tahun sebelumnya. OSDN memiliki 17 bagian yang menunjang kedisiplinan santri, yaitu, bagian sekretaris dan bendahara pusat, olahraga, pengajaran, kebersihan, pertamanan, penerimaan tamu, keputrian, bahasa, keamanan, dan dapur.

\section{Metode}

Metode yang digunakan pada penelitian ini adalah metode penelitian studi kasus dengan pendekatan kualitatif. Penelitian kualitatif adalah penelitian yang bermaksud untuk memahami fenomena tentang apa yang dialami oleh subjek penelitian misalnya perilaku, presepsi, motivasi, tindakan dan lain-lain, secara holistik dan dengan cara deskripsi dalam bentuk katakata dan bahasa, pada suatu konteks yang alamiah dan dengan memanfaatkan berbagai metode alamiah (Moleong, 2008). Data yang dideskripsikan pada penelitian ini adalah fungsi manajemen organisasi HISADA, mulai dari perencanaan, pengorganisasian, pelaksanaan dan pengawasan.

Penelitian ini dilakukan di Pesantren Modern Daarul Uluum Lido, terletak di Jl. HR. Edi Sukma Km 22, desa Ciburuy, kecamatan Cigombong, kabupaten Bogor, provinsi Jawa Barat. Waktu penelitian dimulai pada bulan Oktober 2016 sampai dengan Februari 2017.

Sumber data pada penelitian ini terbagi menjadi dua yaitu, sumber data primer dan sumber data sekunder. Sumber data primer adalah Kepala Bidang Pembinaan dan 
Pengasuhan Santri, guru yang tergabung dalam Bidang Pembinaan dan Pengasuhan Santri, serta santri yang tergabung dalam organisasi HISADA. Sedangkan data sekunder diambil dari majalah Al-Ma'had Pesantren Modern Daarul Uluum Lido serta facebook Daarul Uluum Lido.

\section{Teknik Pengumpulan Data}

Teknik pengumpulan data pada penelitian ini menggunakan teknik observasi, wawancara, dan studi dokumentasi (Sugiyono, 2016). Observasi yang digunakan adalah observasi partisipasi sedangkan wawancara dengan semi terstruktur. Dokumen yang digunakan berupa program kerja HISADA dan foto-foto kegiatan organisasi HISADA.

\section{Teknik Analisis Data}

Teknik analisis data pada penelitian ini menggunakan model analisis Miles dan Hubarman (Yusuf, 2015). Komponen analisis berupa reduksi data, pengumpulan data, display data dan verifikasi.

\section{Pemeriksaan Keabsahan Data}

Pemeriksaan data dilakukan dengan kredibilitas, dengan teknis pemeriksaan berupa perpanjangan waktu penelitian, ketekunan peneliti dan triangulasi data.

\section{HASIL DAN PEMBAHASAN}

\section{Perencanaan dalam Organisasi HISADA}

Perencanaan adalah langkah awal dalam sistem organisasi. Perencanaan merupakan pangkal dari hal yang hendak dikerjakan dalam jangka waktu yang panjang dan membutuhkan pemikiran yang matang. Hal ini perlu dilakukan untuk mengantisipasi kegagalan dalam suatu program kerja yang hendak dilaksanakan.

Organisasi HISADA adalah salah satu bentuk manifestasi lembaga pendidikan Pesantren Modern Daarul Uluum Lido yang memiliki slogan siap memimpin dan siap dipimpin. Keberadaan organisasi HISADA adalah dasar pengurus HISADA untuk berorganisasi dan menumbuhkan jiwa kepemimpinan yang menjadi bekal untuk pengurus HISADA ketika terjun ke masyarakat (hasil wawancara dengan Kepala Pembinaan dan Pengasuhan Santri, ust Ujang Musa).

Fungsi dan tujuan dibentuknya organisasi HISADA adalah untuk membantu pimpinan pesantren dan asatidz untuk menegakkan disiplin para santri dari berbagai aspek dalam kehidupan sehari-hari santri. Untuk mempersiapkan pengurus HISADA yang baik, beberapa program disiapkan sebelum pengurus HISADA melaksanakan tugas dan kewajiban. Hasil wawancara dengan kepala BPPS, Ust Ujang Musa, kegiatan tersebut adalah Training of Leadership and Management (TLM). Dalam kegiatan tersebut, pengurus HISADA diberikan materi kepemimpinan dan kegiatan outboand untuk melatih kerjasama tim, ketika nanti mereka menjadi pengurus HISADA.

Setelah kegiatan tersebut dilakukan, selanjutnya pengurus HISADA yang terpilih sebanyak lima orang melakukan kampanye dan debat kandidat. Guru pembina bagian mengajukan beberapa pertanyaan yang berkaitan dengan organisasi HISADA dengan disaksikan oleh seluruh santri. Dari kegiatan ini-lah santri dapat melihat para calon pemimpin mereka. Setelah melakukan kampanye, selanjutnya pengurus HISADA melaksanakan kegiatan pemilihan umum pengurus HISADA. 
Organisasi HISADA menerapkan sistem demokrasi, dari santri, oleh santri, dan untuk santri (hasil wawancara dengan pengurus HISADA, Siti Humaeroh). Sehingga pemilihan ketua HISADA pun dipilih oleh santri kelas XI sebagai pengurus HISADA. Sistem pemilihan ketua HISADA murni, adil, bebas, dan jujur. Sebelum ketua HISADA dipilih oleh teman sepengurusan, calon ketua HISADA yang jumlahnya lima orang, melakukan debat kampanye calon ketua HISADA. Dalam hal ini kita bisa melihat manakah calon yang layak untuk menjadi ketua HISADA. Debat kampanye ini disaksikan oleh seluruh santri Pesantren Modern Daarul Uluum Lido. Beberapa calon tersebut diberikan pertanyaan seputar organisasi HISADA oleh guru pembina HISADA. Setelah itu para pengurus HISADA dilantik oleh pimpinan pesantren dalam acara serah terima jabatan dengan disaksikan oleh seluruh dewan guru dan santri Pesantren Modern Daarul Uluum Lido. Dalam kegiatan ini pengurus HISADA membacakan ikrar pengurus HISADA yang dipandu oleh pimpinan pesantren dengan sumpah Al-Qur'an.

Untuk melaksanakan program kerja selama satu tahun ke depan, pengurus HISADA melakukan musyawarah kerja yang dihadiri oleh kepala Bidang Pembinaan dan Pengasuhan Santri (BPPS) beserta guru pembina setiap bagian dalam organisasi HISADA. Waktu yang dibutuhkan dalam menyusun program kerja adalah satu minggu (hasil wawancara dengan guru pembina bagian pada organisasi HISADA, ust Muhammad Rajib). Penyusunan program kerja dalam jangka waktu seminggu namun program-program tersebut sudah terfikirkan sejak pengurus menjadi anggota, dilihat berdasarkan kekurangan-kekurangan dari pengurus HISADA pada tahun sebelumnya (hasil wawancara dengan ketua HISADA, Syarifah Abidiyah).

Rapat musyawarah kerja ini dibagi menjadi tiga sesi. Sesi pertama adalah sidang komisi. Pada sidang komisi tersebut, pengurus HISADA di setiap bagiannya mengajukan rencana program kerja untuk dimusyawarahkan bersama guru pembina bagian HISADA. Sesi selanjutnya adalah sidang pleno. Pada sesi ini pengurus HISADA didampingi kepala BPPS dan guru pembina bagian memaparkan program kerja yang telah disepakati bersama. Setiap ketua bagian maju untuk membacakan program kerja bagian terkait. Jika program kerja tersebut telah disepakati bersama, maka ketua HISADA mengetuk palu, tanda bahwa program kerja tersebut telah disepakati bersama. Sesi terakhir adalah sidang paripurna. Para ketua bagian dalam organisasi HISADA membacakan hasil musyawarah kerja dihadapan pimpinan pesantren, kepala BPPS, dan guru pembina organisasi HISADA.

Program kerja yang dimusyawarahkan oleh pengurus HISADA berjangka waktu satu tahun. Tidak hanya program kerja saja yang dibuat, tetapi pengurus HISADA menyusun anggaran yang diperlukan selama satu tahun ke depan. Hal tersebut dapat dikategorikan sebagai perencanaan oprasional. Perencanaan yang dilakukan untuk kepentingan selama satu tahun ke depan.

Menurut analisa peneliti berdasarkan perencanaan untuk mempersiapkan calon pengurus HISADA maupun perencanaan program kerja dan anggaran yang dilakukan oleh pengurus HISADA sudah baik. Pengurus HISADA menyusun program kerja dan anggaran sebagai penunjang dalam melaksanakan tugas sebagai pengurus HISADA. Hanya waktu satu minggu rasanya kurang efektif untuk menyusun program 
kerja meskipun sebetulnya pengurus HISADA sudah memikirkan program kerja tersebut saat pengurus menjadi anggota, berdasarkan kekurangan-kekurangan yang ada pada pengurus HISADA sebelumnya. Mengingat jumlah santri yang banyak dan kegiatan untuk satu tahun ke depan harus benar-benar dipikirkan secara matang agar dapat terlaksanan dengan baik.

\section{Pengorganisasian dalam Organisasi HISADA}

Pengorganisasian merupakan proses penyusunan dan pengelompokkan manusia yang terbentuk dalam sebuah struktur. Dalam struktur tersebut dijelaskan tugas dan kewajiban yang harus dilaksanakan berdasarkan rencana yang telah ditetapkan. Hal ini perlu dilakukan agar tidak terjadi tumpang tindih dalam melaksanakan tugas.

Beberapa pihak yang terlibat dalam penyusunan organisasi adalah kepala bidang pembinaan dan pengasuhan santri, guru pembina bagian, ketua dan wakil ketua HISADA terpilih (hasil wawancara dengan kepala BPPS, ust H. Ujang Musa). Agar program kerja yang telah dibuat dapat berjalan dengan baik, maka selanjutnya pengurus HISADA membentuk struktur organisasi dan penyusunan personalia beserta tugas dan tanggung jawabnya. Dalam organisasi HISADA terdapat beberapa bagian yang menunjang kerja pengurus HISADA yang diambil dari beberapa aspek kehidupan sehari-hari santri. Seperti ketua, wakil, sekretaris, bendahara, bagian keamanan, bagian bahasa, bagian olahraga dan kesehatan, bagian kesenian, bagian logistik dan bagian kepramukaan.

Ketua HISADA dipilih langsung oleh santri kelas XI Madrasah Aliyah, melalui pemilihan umum yang dilaksanakan secara jujur, adil, murni dan bebas (hasil wawancara yang dilakukan oleh salah satu pengurus HISADA, Siti Humaeroh). Selanjutnya ketua dan wakil HISADA terpilih menyusun struktur organisasi pengurus HISADA. Setelah itu pengurus HISADA menyerahkan struktur tersebut untuk dimusyawarahkan kembali dengan kepala BPPS dan guru pembina bagian dalam organisasi HISADA.

Ketua dan wakil ketua dalam organisasi HISADA menempatkan kawan-kawan sepengurusan berdasarkan minat dan bakat yang dimiliki saat menjadi anggota. Namun dalam hal ini, masih saja ada pengurus HISADA yang mengeluh dan kecewa saat bagian yang dinginkan tidak sesuai dengan kemampuan dan keinginannya (hasil wawancara dengan ketua HISADA Syarifah Abidiyah). Hal ini berdasarkan wawancara dengan pengurus HISADA. Struktur organisasi HISADA yang telah dimusyawarahkan kembali dengan kepala BPPS dan guru pembina, dibacakan saat acara serah terima jabatan. Dari situlah pengurus HISADA tahu bagian apa yang didapat.

Pengorganisasian yang dilakukan pada organisasi HISADA sudah berjalan dengan baik, karena struktur organisasi sebagai penunjang telah dilaksanakan dengan beberapa tahapan. Mulai dari penentuan tujuan, penyusunan tugas, penempatan orang sampai terbentuknya struktur organisasi. Hanya saja timbul masalah yang terjadi akibat penyusunan struktur organisasi yang telah diajukan oleh ketua dan wakil HISADA dan dimusyawarahkan kembali oleh kepala BPPS dan guru pembina HISADA. Pengurus HISADA mengeluh karena bagian yang sudah diajukan sebelumnya berubah berdasarkan hasil musyawarah kepala BPPS dan guru pembina. Perlu adanya komunikasi yang baik antara guru pembina dan pengurus 
HISADA agar tidak terjadi kesalahpahaman sehingga hal tersebut tidak menjadi hambatan dalam melaksanakan tugas sebagai pengurus HISADA.

\section{Pelaksanaan dalam Organisasi HISADA}

Setelah program kerja dan struktur organisasi HISADA telah disusun, maka selanjutnya pengurus HISADA melaksanakan program kerja tersebut kepada kawan sepengurusan dan santri di luar pengurus HISADA. Program kerja yang disusun meliputi beberapa aspek kedisiplinan dalam mematuhi tata tertib pesantren. Berikut ini dalah program kerja HISADA yang terbagi menjadi beberapa bidang ekstrakulikuler:

\section{Pembinaan Ibadah dan Akhlak (Bagian Peribadatan)}

Sebagai siswa yang sekaligus santri pesantren maka sudah seyogyanya mereka memiliki akhlak yang baik yang didukung oleh ibadah yang baik pula, maka pengurus HISADA menerapkan disiplin sebagai alat untuk mengarahkan para santri agar menuju output yang diinginkan dengan cara mewajibkan santri untuk shalat berjamaah di masjid, mengadakan program untuk mengajarkan tata cara berwudhu dan sholat berjama'ah untuk santri baru maupun lama, dan mewajibkan santri untuk membaca AlQur'an pada waktu yang telah ditentukan.

\section{Pembinaan Fisik/Jasmani (Bagian Olahraga dan Kesehatan)}

Setelah pembinaan rohani dalam beribadah maupun akhlak terus- menerus ditingkatkan, perlu juga dilakukan pembinaan fisik atau jasmani santri agar terhindar dari penyakit. Agar pembinaan jasmani ini berjalan sesuai dengan harapan, maka para pengurus HISADA membuat beberapa aturan yang memungkinkan siswa untuk dapat menjaga kebugaran jasmani, bahkan lebih dari itu menjadi olahragawan profesional di bidangnya. Program kerja pengurus HISADA pada pembinaan fisik/jasmani adalah mewajibkan santri memiliki klub olahraganya masing - masing, mengadakan senam dan lari pagi seminggu sekali, dan mewajibkan para anggota untuk membersihkan kamar.

\section{Pengembangan Minat dan Bakat (Bagian Kesenian)}

Masing - masing santri sebenarnya memiliki minat dan bakat yang baik. Namun, minat dan bakat mereka tidak akan bisa mereka dapatkan jika pengelolaan dan manajemennya tidak mendukung. Oleh karena itu, kepala Bidang Pembinaan dan Pengasuhan Santri membuat pola sederhana yang diharapkan menjadi alat untuk menggali potensi minat dan bakat para santri di Pesantren Modern Daarul Uluum Lido. Berikut beberapa pola yang ditetapkan oleh para pengurus HISADA membuat klub - klub kursus pada bidang masing - masing, mengontrol jalannya ekstrakulikuler pada bidang kesenian dan membuat serta menetapkan jadwal dan tempat pelaksanaan kursus.

Adapun program tahunan yang menjadi ajang untuk mengembangkan minat dan bakat santri dalam bidang seni dan olahraga adalah kegiatan DUSL (Daarul Uluum Lido Super League). Dalam hal ini pengurus HISADA menjadi panitia untuk mensukseskan acara tersebut. Para santri yang mengikuti lomba merupakan utusan dari setiap rayon (gedung kamar). Para pengurus HISADA yang berada di rayon tersebut membantu para santri untuk mempersiapkan diri mengikuti perlombaan dalam cabang seni dan olahraga.

Menurut analisis peneliti, kegiatan tersebut dapat melatih jiwa kepemimpinan 
santri khususnya pengurus HISADA. Hal ini dapat terlihat dari tugas pengurus HISADA sebagai panitia penyelenggara dan membantu para anggota untuk mempersiapkan lomba.

\section{Pembinaan Disiplin Bahasa Santri (Bagian Bahasa)}

Bahasa merupakan salah satu alat untuk berkomunikasi dengan sesama manusia. Bahasa Arab dan Inggris menjadi bahasa pengantar bagi seluruh santri yang berada di Pesantren Modern Daarul Uluum Lido. Pengurus HISADA dan santri memiliki kewajiban untuk berbicara dengan menggunakan dua bahasa tersebut, baik di dalam kelas maupun di luar kelas. Untuk menegakkan disiplin berbahasa, pengurus HISADA membuat program kerja seperti, mengontrol jalannya kegiatan muhadhoroh dan muhadatsah, memberikan kosakata baru berbahasa Arab dan Inggris setiap pagi, mengadakan perlombaan pidato berbahasa Indonesia, Arab, dan Inggris, serta menciptakan lingkungan berbahasa.

\section{Pembinaan Disiplin Keamanan Santri (Bagian Keamanan)}

Pembinaan disiplin merupakan pembinaan yang mutlak diadakan oleh setiap lembaga pendidikan. Pembinaan dalam hal disiplin bertujuan agar santri tidak keluar dari jalur yang diharapkan oleh Pesantren Modern Daarul Uluum Lido. Pembinaan secara disiplin meliputi semua aspek yang berkaitan dengan keberadaan santri dari pagi hari ketika bangun dari tidur, masuk kelas, hingga kembali ke asrama masing masing.

Pembinaan kedisiplinan ini terutama yang sedikit memaksa para santri untuk mengikuti aturan manajemen. Membuat para santri untuk mematuhi aturan yang telah dibuat, hal ini mengajarkan mereka untuk berpikir lebih praktis dan berpikir lebih matang dalam melakukan suatu tindakan. Sedangkan kegunaan pembinaan disiplin bagi para pengurus yaitu menempatkan diri sebagai penegak disiplin yang menuntut mereka untuk bersikap, berpakaian lebih sempurna dari pada para anggota dan santri yang lain.

Program yang dibuat oleh pengurus HISADA untuk menegakkan kedisiplinan dan keamanan santri di pesantren seperti, menggerakkan seluruh anggota untuk berangkat ke sekolah dan acara pesantren, menyita barang-barang yang tidak diperbolehkan untuk dipakai di pesantren dan mengontrol anggota pada malam hari untuk tidur tepat pada waktunya.

\section{Bagian Logistik}

Bagian logistik adalah bagian yang tugasnya menyiapkan alat-alat yang dibutuhkan saat acara yang berkaitan dengan pengurus HISADA berlangsung. Tugas pada bagian logistik HISADA yaitu, memutarkan lantunan ayat suci Al-Quran sebelum sholat lima waktu, membersihkan peralatan sound system dan menempelkan surat kabar ke Mading pesantren sebagai tambahan informasi untuk para santri.

\section{Pembinaan Kepramukaan (Bagian Kepramukaan)}

Pembinaan kepramukaan saat ini sudah merupakan kewajiban tiap-tiap lembaga pendidikan. Seiring dengan berkembangnya dunia pendidikan, maka pramuka dianggap sebagai kegiatan ekstrakulikuler yang wajib diikuti oleh siswa di masing-masing sekolah. Terutama di Pesantren Modern Daarul Uluum Lido. Pembinaan kepramukaan dilaksanakan lebih intensif dengan membuat pasukan - pasukan khusus yang menguasai materi kepramukaan lebih banyak dan lebih baik dari teman temannya yang lain. 
Kegiatan dalam bidang kepramukaan yang telah disusun oleh pengurus HISADA yaitu, membuat jadwal petugas upacara per Gudep, menyediakan atribut perlengkapan pramuka, dan mengadakan cross country

\section{Bagian Rayon}

Bagian rayon adalah bagian yang menangani kegiatan santri di setiap kamar. Jumlah rayon (gedung asrama santri) adalah 16 asrama, 8 asrama untuk laki-laki dan 8 untuk asrama perempuan. Setiap asrama terdiri dari beberapa kamar. Tugas pengrus HISADA pada bagian rayon ini adalah untuk mengarahkan santri agar berdisiplin di pesantren. Mengontrol santri di dalam kamar.

Sejauh ini organisasi HISADA telah berjalan sesuai dengan fungsinya. Meskipun hal ini belum berjalan secara keseluruhan. HISADA merupakan ujung tombak pesantren. Seluruh kegiatan santri dilaksanakan oleh pengurus HISADA (hasil wawancara dengan Ketua HISADA putra, Rakha Fadhil). Beberapa hambatan dialami pengurus HISADA dalam menjalankan tugasnya. Hambatan tersebut berasal dari diri pengurus yang masih merasa malas dan lalai serta kurangnya kesadaran terhadap program kerja dan peraturan yang telah dibuat oleh pengurus HISADA itu sendiri (hasil wawancara dengan guru pembina HISADA, ust M. Rajib).

Fasilitas yang kurang mendukung juga menjadi salah satu faktor yang menghambat dalam melaksanakan program kerja. Selain itu adanya perbedaan pendapat antara pembina dan pengurus HISADA kerapkali terjadi dalam menjalankan tugas pengurus HISADA.

Kegiatan yang dilakukan dalam organisasi HISADA memberikan kontribusi yang positif dalam melatih jiwa kepemimpinan santri, khususnya santri kelas XI Madrasah Aliyah yang menjabat sebagai pengurus HISADA. Kegiatan dalam organisasi HISADA memberikan kontribusi yang sangat positif dalam melatih jiwa kepemimpinan santri khususnya santri kelas XI yang menjabat sebagai pengurus. Permasalahan yang mereka hadapi dalam organisasi HISADA, melatih mrereka untuk mengembangkan sikap kepemimpinan (hasil wawancara dengan kepala BPPS, ust Ujang Musa). Mereka dilatih untuk disiplin, berkomitmen dengan program kerja yang sudah disusun dan bertanggung jawab.

Status pengurus HISADA sebagai santri yang harus melaksanakan kewajibannya juga sebagai seorang pelajar dan mengurus santri. Dengan banyaknya tugas sekolah maupun tugas organisasi, pengurus HISADA dituntut untuk memiliki kesabaran, kebijaksanaan, dalam menghadapi masalah. Pengurus HISADA dituntut untuk bersikap tegas terhadap terhadap santri yang melanggar aturan serta membimbing santri agar tetap berada dalam koridor yang benar.

\section{Pengawasan dalam organisasi HISADA}

Agar semua rencana dan program kerja yang telah disusun dengan baik, maka selanjutnya pengawasan dalam menjalankan tugas pengurus HISADA menjadi hal yang penting untuk dilakukan. Pengawasan dilakukan agar program kerja yang telah dibuat tidak keluar dari hal yang telah direncanakan. Orang yang terlibat dalam pengawasan program kerja adalah kepala BPPS, muro'I (pembina bagian), dan pengurus HISADA itu sendiri dan santri sebagai anggota yang diurus oleh pengurus HISADA (hasil wawancara dengan kepala BPPS, ust Ujang Musa). Bentuk pengawasan yang dilakukan oleh organisasi HISADA terbagi menjadi dua. Pertama, pengawasan secara langsung yang dilakukan oleh guru pembina bagian HiSADA dan ketua HISADA 
terhadap pelaksanaan program kerja HISADA. Setiap kegiatan, ketua HISADA melihat kondisi di lapangan, apabila terdapat kekeliruan, ketua HISADA sebagai pimpinan organisasi menegur dan menasehati pengurus tersebut. Kedua, pengawasan tidak langsung melibatkan santri yang ditunjuk sebagai jasus (matamata) untuk melihat kondisi di lapangan dan melaporkannya kepada ketua HISADA ataupun guru pembina untuk ditindak lanjuti. Pengawasan dilakukan dengan melihat langsung kondisi di lapangan dan saya sebagai pengurus HISADA memiliki inisiatif untuk melakukan hijrah hujroh, menginap dari kamar yang satu ke kamar yang lain untuk memastikan program yang telah dibuat berjalan dengan baik. (hasil wawancara dengan ketua HISADA, Syarifah Abidiah).

Pengawasan yang dilakukan secara konsisten dapat memberikan dampak yang positif terhadap kinerja pengurus HISADA. Dalam menjalankan kepengurusan selama satu tahun sudah pasti terdapat rasa lelah dan jenuh. Dengan pengawasan yang selalu dilaksanakan akan memotivasi pengurus HISADA untuk bertanggung jawab dalam melaksanakan tugas sebagai pengurus HISADA. Pengawasan yang dilakukan akan mengurangi tindakan penyelewengan dan seluruh kegiatan dapat terkoordinasi dan terkontrol dengan baik. Sikap guru pembina dalam mengatasi pelanggaran terhadap program kerja yang telah direncanakan kepada pengurus HISADA sebagai bentuk tindakan langsung adalah menegur, memberikan sanksi, dan mengawasi perkembangan yang bersangkutan (hasil wawancara dengan ust M. Rajib)

\section{KESIMPULAN DAN IMPLIKASI}

\section{Kesimpulan}

Penerapan manajemen organisasi dalam organisasi HISADA sebagai wadah kepemimpinan santri sudah cukup efektif dengan adanya program-program kerja dalam membina serta melatih sikap kepemimpinan santri. Fungsi manajemen, mulai dari perencanaan, pengorganisasian, pelaksanaan, dan pengawasan sudah berjalan dengan baik, meskipun masih ada beberapa hal yang menjadi penghambat dalam pelaksanaan organisasi HISADA. Beberapa kegiatan dilakukan sebelum pengurus HISADA melaksanakan tugasnya di lapangan. Seperti kegiatan TLM (Training of Leadership and Management), KMD (Kemahiran Dasar Pramuka), debat dan kampanye calon ketua HISADA, serah terima jabatan dan musyawarah kerja. Perencanaan dalam organisasi HISADA dilakukan melalui musyawarah kerja dengan sesama pengurus HISADA beserta guru pembina HISADA dalam rangka memusyawarahkan hal yang akan dilakukan selama satu tahun ke depan. Musyawarah tersebut dilakukan setelah terbentuknya struktur organisasi yang telah dibentuk oleh pengurus HISADA atas musyawarah dengan kepala BPPS dan guru pembina HISADA. Pengorganisasian yang dilakukan pada organisasi HISADA adalah dengan membentuk struktur organisasi beserta tugas dan susunan personaliannya. Pengurus HISADA terpilih menyusun struktur organisasi kemudian diserahkan kepada kepala BPPS dan dewan guru BPPS untuk dimusyawarahkan kembali. Setelah disusunnya program kerja HISADA dan struktur organisasi, maka pelaksanaan adalah implikasi dari kedua hal tersebut. Pada kegiatan pelaksanaan inilah pengurus melaksanakan beberapa kegiatan yang 
menunjang disiplin santri dalam berbagai bidang, seperti bahasa, keamanan, ibadah, logistik, pramuka, olahraga kesehatan, dan rayon. Pengawasan yang dilakukan dalam organisasi HISADA secara langsung dengan kontrol harian dan secara tidak langsung dengan menunjuk jasus (mata-mata) untuk selanjutnya dilaporkan kepada pimpinan organisasi.

\section{Implikasi}

1. Orang tua santri yang menitipkan buah hatinya ke pesantren, menjadi tanggung jawab bersama. Situasi ini dapat memberikan motivasi tersendiri bagi seluruh dewan guru yang berada di Pesantren Modern Daarul Uluum Lido agar turut serta dalam membimbing dan mengurus para santri terutama dalam kegiatan sehari-hari santri, meskipun tidak tergabung dalam susunan guru pembina organisasi HISADA.

2. Guru pembina HISADA aktif dalam membimbing dan mengarahkan pengurus HISADA dalam melaksanakan tugasnya. Sehingga para santri banyak mendapatkan arahan dan bimbingan dari para guru Pembina.

3. Pengurus HISADA kompak dalam melaksanakan tugasnya sebagai pengurus HISADA. Meskipun banyaknya permasalahan dalam organisasi dan mengurus para santri. Dengan kerja tim yang bagus, segala permasalahan menjadi sebuah pelajaran yang dapat melatih jiwa kepemimpinan para pengurus HISADA sebagai bekal untuk terjun ke masyarakat yang lebih luas.

\section{DAFTAR PUSTAKA}

Badruddin. 2014. Dasar-dasar manajemen. Alfabeta, Bandung.

Bahri MG. 2001. Pendidikan pesantren berwawasan lingkungan. Pedoman Ilmu, Jakarta.

Depdiknas. 2015. Kamus besar Bahasa Indonesia Pusat Bahasa. PT Gramedia Pustaka Utama, Jakarta.

Handoko TH. 2015. Manajemen BPFE Yogyakarta, Yogyakarta.

Kementrian Agama. 2016. Al - Qur'an dan Terjemahan An-Nafi'.

Marno dkk. 2008. Manajemen dan kepemimpinan pendidikan islam. Refika Aditama, Bandung.

Moleong LJ. 2008. Metodologi penelitian kualitatif. PT. Remaja Rosdakarya, Bandung.

MU YAPPI. 2008. Manajemen pengembangan pondok pesantren. PT Listafariska Putra, Jakarta.

Usman H. 2014. Manajemen (teori, praktik, dan riset pendidikan). Bumi Aksara, Jakarta.

Priyono. 2007. Pengantar manajemen. Zifatama Publisher, Surabaya.

Ramayulis. 2008. Metodologi pendidikan agama islam. Kalam Mulia, Jakarta.

Rohadi M dkk. 2008. Rekonstruksi pesantren masa depan. Media Nusantara, Jakarta.

Silalahi U. 2011. Asas-asas manajemen. Refika Aditama, Bandung.

Sugiyono. 2016. Metode penelitian pendidikan. Alfabeta, Bandung.

Yusuf AM. 2015. Metode penelitian kuantitatif, kualitatif, dan penelitian gabungan. Prenada Media Group, Jakarta.

Zenju NS. 2008. Administrasi publik. KITA Press, Surabaya. 